\title{
Design of Wearable Multiband Circular Microstrip Textile Antenna for WiFi/WiMAX Communication
}

\author{
Husain Bhaldar $^{1,2}$, Sanjay Kumar Gowre ${ }^{3}$, Mahesh S Mathpati, ${ }^{2,4}$, Ashish A Jadhav ${ }^{1,2}$, Mainaz S Ustad ${ }^{5}$ \\ ${ }^{1}$ Research Scholar, Department of Electronics and Communication Engineering, Bheemanna Khandre Institute of Technology, \\ Bhalki, affiliated to Visvesvaraya Technological University Jnana Sangama, Belagavi, Karnataka, India. \\ ${ }^{2}$ Assistant Professor, Department of Electronics \& Telecommunication Engineering, Shri Vithal Education and Research \\ Institutes, College of Engineering, Pandharpur, India. \\ ${ }^{3}$ Professor, Department of Electronics and Communication Engineering, Bheemanna Khandre Institute of Technology, Bhalki, \\ India. \\ ${ }^{4}$ Research Scholar, GNDCE Bidar Visvesvaraya Technological University Jnana Sangama, Belagavi, Karnataka, India. \\ ${ }^{5}$ Lecturer, SVIPE, ICMS Kasegaon, India.
}

\begin{abstract}
In proposed design the wearable circular microstrip antenna of radius of patch is $14 \mathrm{~mm}$ and the top of patch consist of two square slits of dimensions $5 \times 5 \mathrm{~mm}^{2}$ and $10 \times 10 \mathrm{~mm}^{2}$ and the ground structure is made partial of $28 \mathrm{~mm} \times 86 \mathrm{~mm}$. Due to the properties of jeans fabric as low cost, flexible the antenna is made wearable. In the proposed study, circular microstrip textile based antenna has been designed for the ISM band of resonating frequency of $2.4 \mathrm{GHz}$. The proposed structure provided the triple band as the radiating frequencies of $2.4 \mathrm{GHz}$ for $\mathrm{WiFi}, 6.4 \mathrm{GHz}$ for WiMAX and $12 \mathrm{GHz}$ for $5 \mathrm{G}$ communication applications. The simulated and fabricated results such as return loss, VSWR and gain - directivity etc. are analyzed and compared for the frequencies of $2.38 \mathrm{GHz}, 6.4 \mathrm{GHz}$ and $12 \mathrm{GHz}$. In this proposed antenna, the bandwidths of antenna are obtained of the order $700 \mathrm{MHz}$, $3.43 \mathrm{GHz} \& 2.75 \mathrm{GHz}$ and gain of antenna are of the order $1.89 \mathrm{dBi}, 3.98 \mathrm{dBi} \& 4.86 \mathrm{dBi}$.
\end{abstract}

KEYWORDS: Circular Microstrip, Multiband, Return Loss, Wi-Fi, WiMAX.

\section{INTRODUCTION}

Wireless communication technology is progressively passing through everybody life. In the present wireless communication wearable antenna (Microstrip Textile Antenna) plays important role due to their structural and light weight characteristics. The emerging trend in the wireless communication technology and increasing interest in the wearable antenna in the field of applications such as medical, rescue and military etc. In the field of wireless communication the light weight antennas are preferred and in this application the antenna gain \& efficiency is kept very high. As antenna theory says the gain and efficiency are proportionally dependent on each other. The fast growth in wearable communication has boosted the need of very small and wide bandwidth antennas. The circular shaped MTA (Microstrip Textile Antenna) well preferred over other structure due to their properties of compact in size, cost effective and ease in fabrication. Nowadays in the wireless communication the multiband antennas are used for mobile applications and Ultra wideband applications.

The frequency range of ISM band is from $2.4 \mathrm{GHz}$ to $2.485 \mathrm{GHz} \&$ used for Wi-Fi communication. The mobile WiMAX is used in three operating frequencies from 2.32.4GHz, 2.5- 2.7GHz and $3.4-3.6 \mathrm{GHz}$. As per the IEEE 798
802.11 to 16 , the WiMAX is used in broadband wireless communication. The frequency band allocated to WiMAX IEEE $802.16 \mathrm{a}$ is varying from $10-16 \mathrm{GHz}$ and for IEEE 802.16d or IEEE802.16-2004 varies from 2- 11GHz. This frequency band is implemented to interface with OFDM or OFDMA for broadband wireless communication.

Nikhil Kumar Singh. et al. (2016) observed that proposed antenna operating at three frequency bands of $3.42 \mathrm{GHz}$, $9.73 \mathrm{GHz} \& 11.17 \mathrm{GHz}$ and it has been used for multiband application. The wearable antenna has been designed on jeans material and used for on human body communication [1].

H.K.Bhaldar. et al. (2020) studied the microstrip textile antenna for Wi-Fi communication and antenna has been resonating at frequency of $2.45 \mathrm{GHz} \&$ provided return loss of $-15.76 \mathrm{~dB}$ with directivity of 8.05 . The antenna is designed with rectangular shape $\&$ jean as dielectric material to get wide bandwidth [2]. Carlos. et al. (2018) designed on body wearable antenna designed at ISM band of frequency $2.45 \mathrm{GHz} \&$ radiated at $-18 \mathrm{~dB}$ of return loss $\&$ also a robust snap on button textile antenna designed at $2.45 \mathrm{GHz}$ and provided return loss of $-25 \mathrm{~dB}[3,4]$. Pranita Manish et al. (2018) observed and analyzed the microstrip textile antenna simulated at $2.45 \mathrm{GHz}$ with different dielectric fabric materials such as Cotton, Polyester, Cordura and Lycra. The 
values of return losses at $2.45 \mathrm{GHz}$ frequency for respective textile material have studied $-32 \mathrm{~dB},-35 \mathrm{~dB},-29 \mathrm{~dB}$ and $-31 \mathrm{~dB}$ $[5]$.

Anurag Saxena. et al. (2018) designed the antenna operating at the multiple frequencies from $5.3 \mathrm{GHz}$ to $10.15 \mathrm{GHz}$ and provided the bandwidth of $62.78 \%$, return loss of $-25 \mathrm{~dB}$ at $5.44 \mathrm{GHz} \&-24 \mathrm{db}$ at $8.05 \mathrm{GHz}$. The author used the moon strip line structure of patch [6]. Idellyse and Rama Reddy. et al.(2018) proposed the circular polarized textile antenna and $\mathrm{U}$ slot conical antenna which is designed at ISM band of frequency range $2.4 \mathrm{GHz}$ to $2.45 \mathrm{GHz}$, the values of $\mathrm{S} 11$ parameter $-35 \mathrm{~dB} \&-20 \mathrm{~dB}$ are observed at resonating frequency[7-8].

Sweety Purohit. et al. (2014) simulated the light weight wearable antenna using jeans material at the resonant frequency of $2.45 \mathrm{GHz}$. When antenna used for on body communication, the SAR is very important parameter considered for wearable application and the standard SAR value used is of $1.6 \mathrm{~W} / \mathrm{kg}$ of tissue [9]. Jiahao Zhang et.al (2017) observed the miniature feeding network for aperture coupled antennas designed at frequency of $2.4 \mathrm{GHz}-$ $2.483 \mathrm{GHz}$ with gain of $5.6 \mathrm{dBi}$. The author have studied various shapes of coupling aperture such as ring, H-shaped, rectangular, E shaped, cross etc. at various frequencies in ISM band [10].

The Yiye Sun. et al. (2014) designed the circular patch with thin feed line and has rectangular ground plane. The bandwidth of designed antenna has been enhanced due to use of tapered feed line. The proposed antenna used at ultra-wide band application for frequency range of $2.8 \mathrm{GHz}$ to $16 \mathrm{GHz}$ [11]. Punith S. et al. (2020) studied and the implemented the multiband antenna resonating at $23.9 \mathrm{GHz}, 35.5 \mathrm{GHz}$ and $70.9 \mathrm{GHz}$ and used for $5 \mathrm{G}$ communication. The antenna has been analyzed to achieve the return losses of $-19.97 \mathrm{~dB}$, $22.73 \mathrm{~dB}$ and $-21.96 \mathrm{~dB}$ for the above mentioned operating frequencies [12]. S. Kumar. et al. (2018) analyzed and implemented the co-planar fed antenna at ISM band for implantable on the body with bio sensor for on body communication. The proposed antenna designed with loop structure and it is radiating with return loss of $-37 \mathrm{~dB}$ [13]. Seyed Mohsen. et al. (2019) designed the multiband CPW fed microstrip wearable antenna for operating frequency of $3.2 \mathrm{GHz}$ to $16.3 \mathrm{GHz}$ for ultra-wide band application.

The compact antenna is implemented on the body and in the air; the efficiency observed on the body is greater than in the air located antenna [14]. Sandeep Singh Sran. et al. (2020) studied and analyzed the wearable fractal antenna operating at $2.53 \mathrm{GHz}, 4.9 \mathrm{GHz}$ and $7.6 \mathrm{GHz}$ for $\mathrm{S}, \mathrm{C}$, and $\mathrm{X}$ band application. The proposed antenna improved the gain and bandwidth at these resonant frequencies [15]. A. Deviovanni. et al. (2018) proposed the high gradient linacs for hadron therapy for the frequency range of 3 to $5.7 \mathrm{GHz}$. The proton beams are radiated by using hadron therapy with energies 70 and 230Mev [16].
After doing the literature survey, the proposed antenna design focused on the improvement of the gain and bandwidth of antenna.

\section{METHODOLOGY}

\subsection{Microstrip Antenna}

Microstrip antenna is most preferred antenna among all printed antenna due to its properties such as light in weight, low cost \& ease of installation. In today's era microstrip patch antenna widely used for wireless communication. The geometry of microstrip patch antenna consist of top patch \& bottom ground plane separated by dielectric materials such as FR4, Rogger etc. as shown in figure 1. In case of wireless applications, the various structures of microstrip patch antenna are used such as square, rectangular, circular and triangular etc.

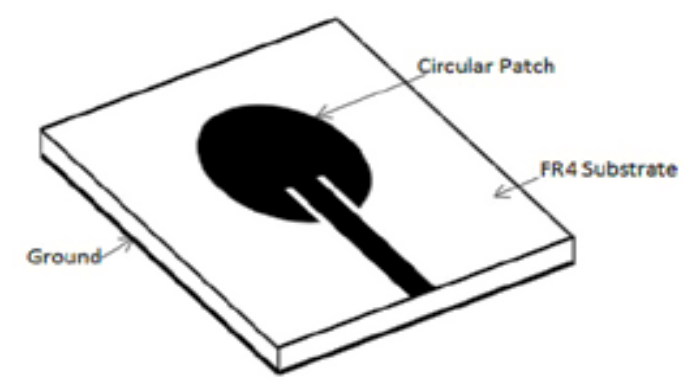

Figure 1: Microstrip Patch Antenna

\subsection{Proposed Model}

The proposed circular microstrip textile antenna has been designed for Wi-Fi communication at the frequency of $2.4 \mathrm{GHz}$ with radius of patch $14 \mathrm{~mm}$ is calculated as shown in equation 1 .The figure 2 a shows geometry of designed circular antenna which consist of top patch with two square slits of dimensions $5 \mathrm{~mm} \times 5 \mathrm{~mm}$ and $10 \mathrm{~mm} \times 10 \mathrm{~mm}$ provide the extra frequency band. The one more extra frequency band have been achieved by using partial ground of partial ground of $86 \mathrm{~mm} \times 28 \mathrm{~mm}$ which is shown in figure $2 \mathrm{~b}$. The circular microstrip textile antenna has made with copper foil of thickness 35 micron and the dielectric substrate used as jean material with relative permittivity of $1.7 \&$ height of material $1 \mathrm{~mm}$. The designed antenna is excited with voltage source connected to microstrip feed line of impedance $55 \mathrm{ohm}$. The study of microstrip antenna stated that, the inverse relation between the bandwidth and the dielectric constant $\varepsilon_{\mathrm{r}}$. When the dielectric constant value is decreasing, the bandwidth of antenna is increasing. So this method is implemented proposed study of antenna design.

It has been observed that the proposed geometry of antenna radiating at two extra bands of frequencies $6.4 \mathrm{GHz}$ $\& 12 \mathrm{GHz}$ which is used for WiMAX and $5 \mathrm{G}$ communication. The $5 \mathrm{G}$ communication band can be used from $3.5 \mathrm{GHz}$ to $300 \mathrm{GHz} \&$ the WiMAX frequency band used from $2 \mathrm{GHz}$ to $8 \mathrm{GHz}$. So proposed antenna have provided the three frequency bands $2.32 \mathrm{GHz}, 6.4 \mathrm{GHz} \& 11.95 \mathrm{GHz}$ used for $\mathrm{Wi}$ $\mathrm{Fi}$, WiMAX \& $5 \mathrm{G}$ communication. The designed antenna is 
"Design of Wearable Multiband Circular Microstrip Textile Antenna for WiFi/WiMAX Communication"

compact in size and provided enhanced bandwidth which is requirement of wearable application.

The proposed microstrip textile antenna has been simulated in CST microwave studio software and the various antenna parameters have been analyzed. The figure 3 shows geometry of fabricated microstrip textile antenna and it is tested using VNA of $20 \mathrm{GHz}$ frequency.

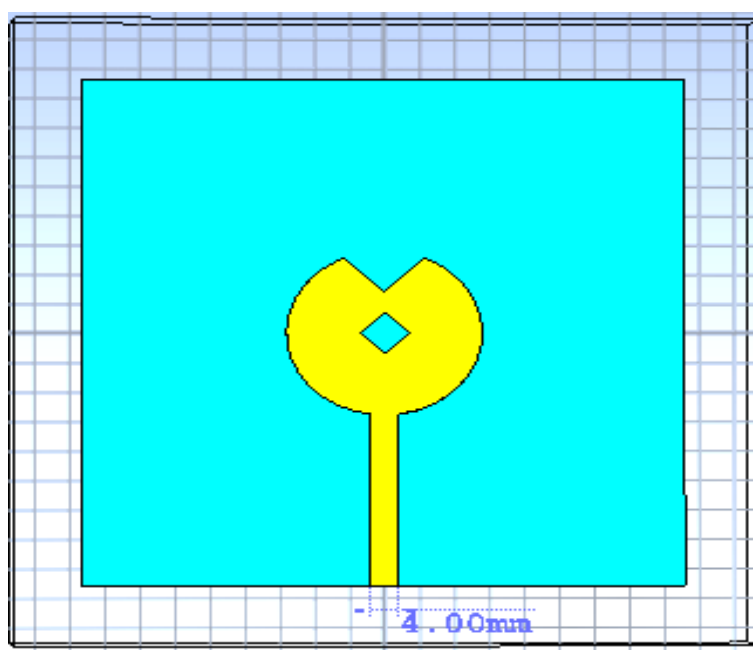

$2 \mathrm{a}$

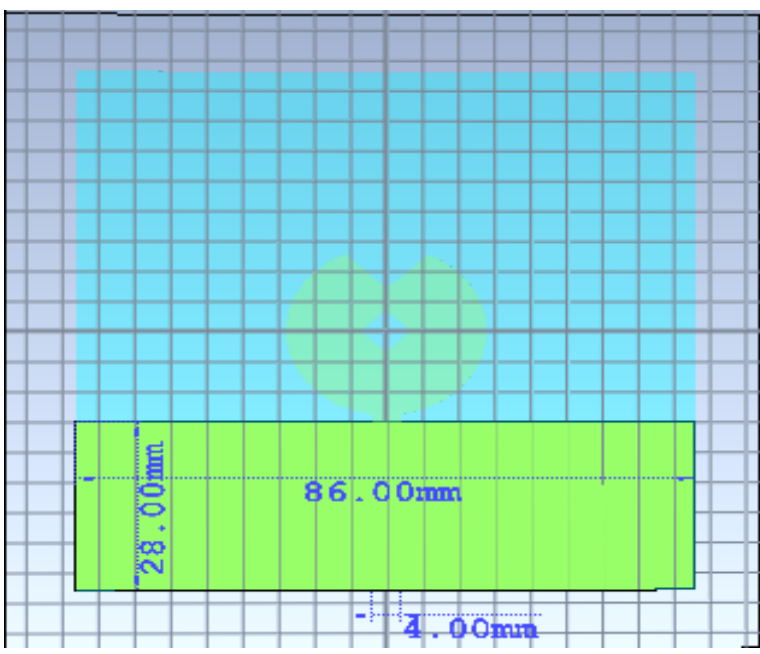

$2 b$

Figure 2: Proposed antenna 2a: Top patch of proposed antenna \& 2b: Ground plane of proposed antenna
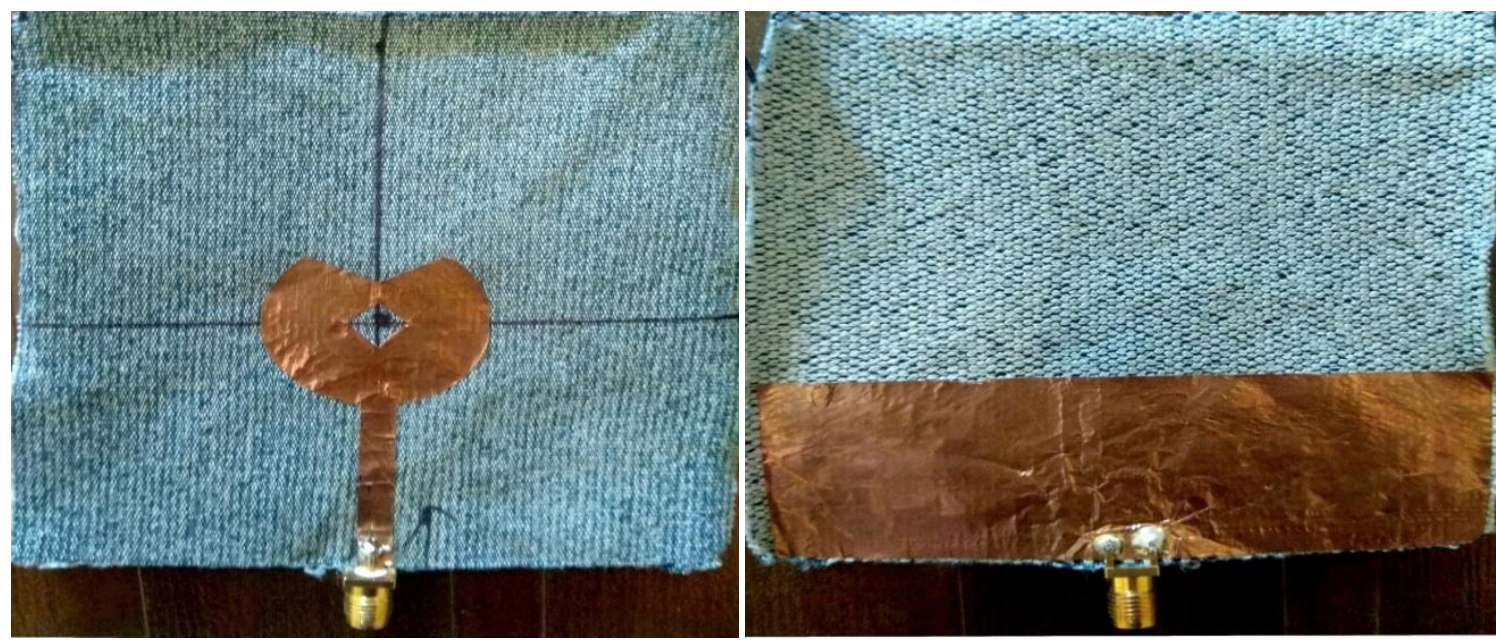

Figure 3: Fabricated circular microstrip textile antenna.

The radius of circular patch microstrip antenna is calculated for resonant frequency of $2.4 \mathrm{GHz} \&$ dielectric constant of 1.7 by using equation $1[2]$.

$$
\begin{aligned}
& \mathbf{f}_{\mathbf{m n}}=\frac{\mathbf{c}}{2 \pi \mathbf{a} \sqrt{\varepsilon \mathbf{r}}} \mathbf{x}_{\mathbf{m n}} \\
& \text { Where } \quad \mathbf{c}=\frac{\mathbf{1}}{\sqrt{\boldsymbol{\mu}_{\mathbf{0}} \boldsymbol{\varepsilon}_{\mathbf{0}}}} \text { speed of light } \\
& \mathrm{F}_{\mathrm{mn}}=\text { Resonating frequency for mn mode }
\end{aligned}
$$

$$
\mathrm{a}=\text { Radius of patch }
$$$$
\mathrm{X}_{\mathrm{mn}}=\text { Constant for mn mode }
$$

$\varepsilon r=$ Relative dielectric constant of substrate

The table 1 shows that the list of antenna parameter used design circular microstrip antenna

Table 1: List of Antenna Parameter

\begin{tabular}{ll}
\hline Antenna Parameter & Value \\
\hline Dielectric constant $\varepsilon \mathrm{r}$ & 1.7 \\
Radius of patch a & $14 \mathrm{~mm}$ \\
Length of slitL1 & $5 \mathrm{~mm}$ \\
Width of slit W1 & $5 \mathrm{~mm}$ \\
Length of slitL2 & $10 \mathrm{~mm}$ \\
Width of slit W2 & $10 \mathrm{~mm}$ \\
\hline
\end{tabular}


"Design of Wearable Multiband Circular Microstrip Textile Antenna for WiFi/WiMAX Communication"

\begin{tabular}{lll}
\hline Ground plane length $\mathrm{Lg}$ & $28 \mathrm{~mm}$ \\
Ground plane width $\mathrm{Wg}$ & $86 \mathrm{~mm}$ \\
Width of feed line Wf & & $4 \mathrm{~mm}$ \\
Substrate height & hs & $1 \mathrm{~mm}$ \\
Substrate thickness & ht & $0.035 \mathrm{~mm}$ \\
\hline
\end{tabular}

3. Result \& Discussion: In order to get best analysis \& validation, the comparison of simulated and the measured return loss, VSWR and bandwidth values of proposed antenna are discussed.

I) Return Loss: For the perfect radiation the value of return loss must be maintained at minimum -10dB. From figure 4 , it has been observed that designed antenna have provided the triple bands $\&$ the values of return losses are $31.827 \mathrm{~dB}$ at a frequency of $2.3268 \mathrm{GHz},-20.227 \mathrm{~dB}$ at a frequency of $6.47 \mathrm{GHz}$ and $-14.42 \mathrm{~dB}$ at a frequency of
$11.952 \mathrm{GHz}$. The bandwidths observed at these frequency bands are $0.7 \mathrm{GHz}, 3.43 \mathrm{GHz}$ and $2.75 \mathrm{GHz}$ at $-10 \mathrm{~dB}$ of the return loss plot. The above said bandwidths have been enhanced by using low value of dielectric constant of jean and partial ground structure. The simulated and fabricated results are also achieved same which is shown in figure 5 and table no. 3 .

The fractional bandwidth also calculated using formula $\%$ Fractional $\mathrm{BW}=\mathrm{F}_{\mathrm{H}}-\mathrm{F}_{\mathrm{L}} / \mathrm{F}_{\mathrm{c}} \quad$ eq (2)

The results of fractional bandwidths are shown table $2 \& 3$ of simulated results and fabricated results.

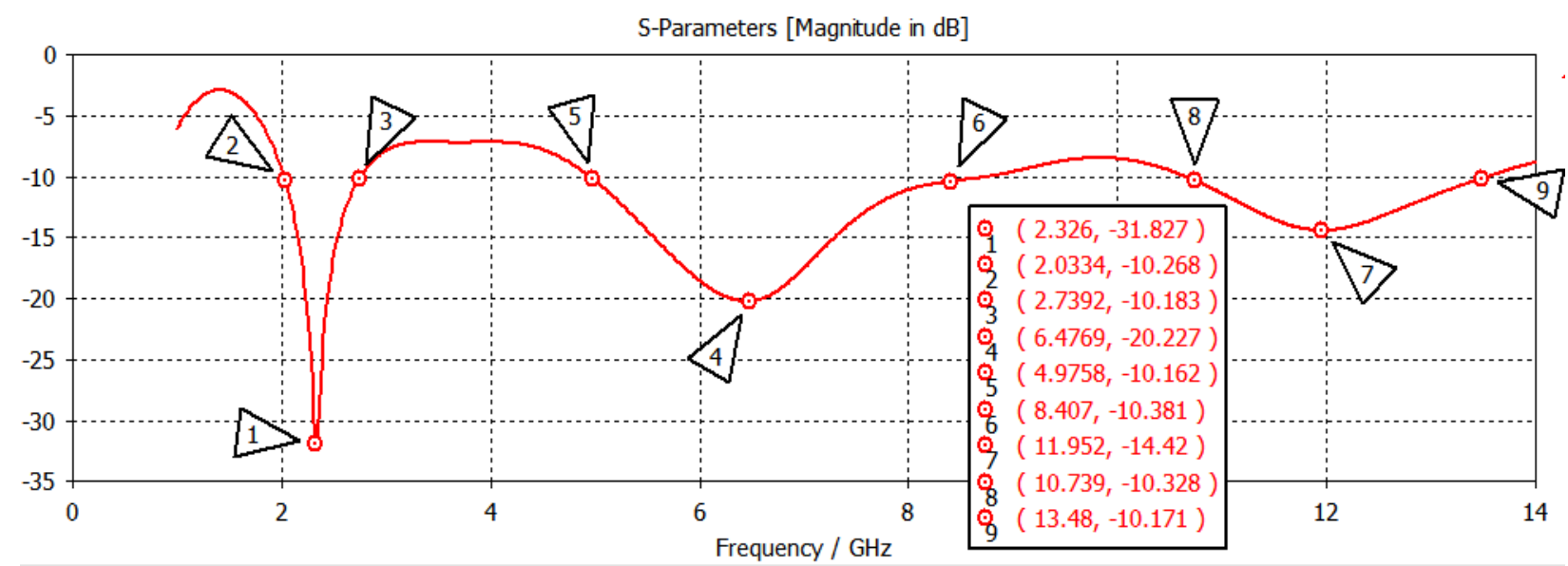

Figure 4: Return Loss in $\mathrm{dB}$ at $2.32 \mathrm{GHz}, 6.47 \mathrm{GHz} \& 11.95 \mathrm{GHz}$

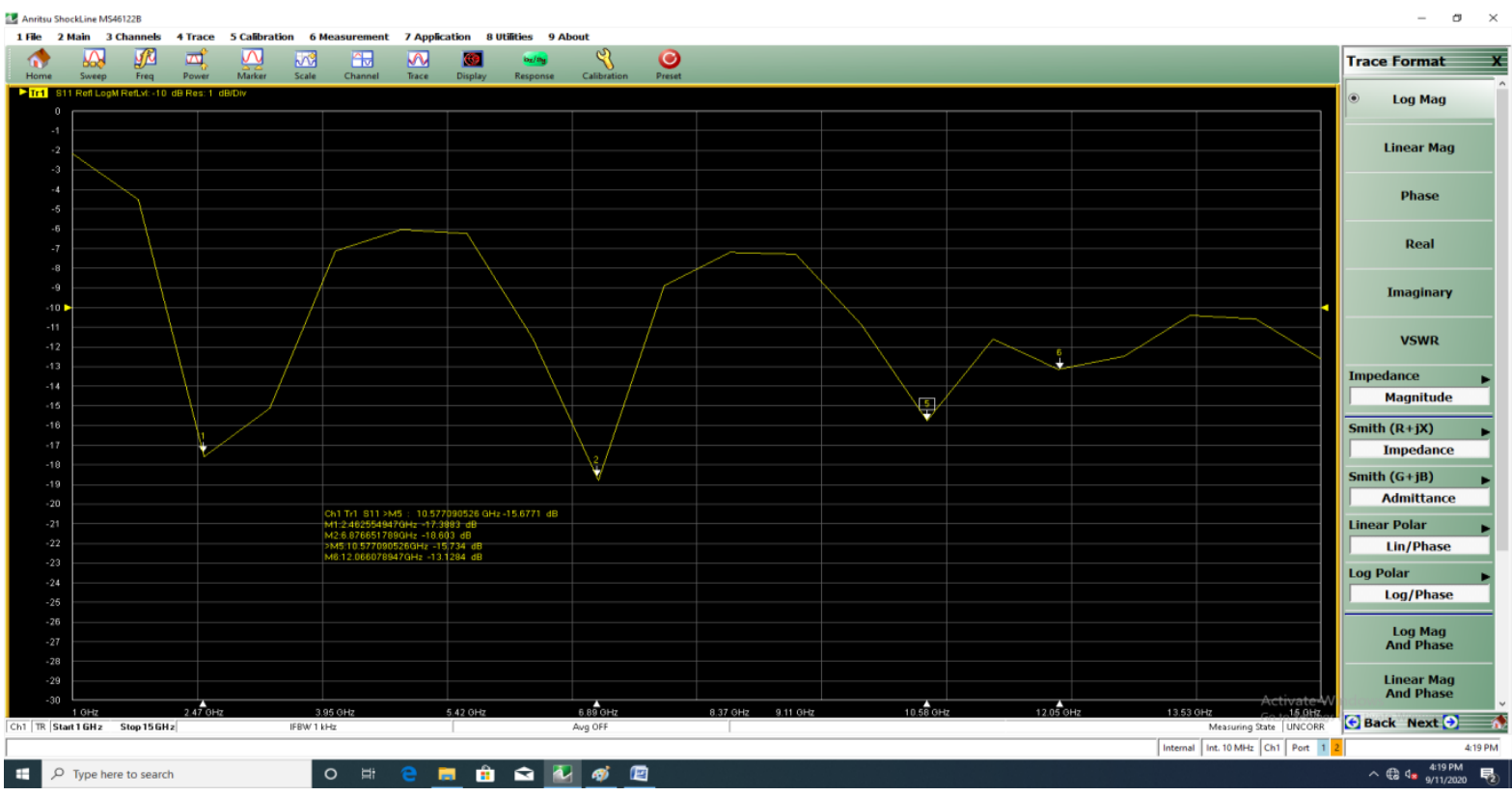

Figure 5: Return Loss of fabricated antenna tested on VNA 
Table 2: comparison of simulated \& fabricated results

\begin{tabular}{|c|c|c|c|c|c|c|}
\hline $\begin{array}{l}\text { Sr. } \\
\text { No. }\end{array}$ & Parameter & $\begin{array}{l}\text { Resonating } \\
\text { Frequency }(\mathbf{G H z})\end{array}$ & S11 in $\mathrm{dB}$ & VSWR & $\begin{array}{l}\text { Bandwidth } \\
\text { in GHz }\end{array}$ & $\begin{array}{l}\text { \% Fractional } \\
\text { BW }\end{array}$ \\
\hline 1 & Simulated & $2.32,6.47 \& 11.95$ & $\begin{array}{l}-31.8,-20.2 \&- \\
14.4\end{array}$ & $\begin{array}{l}1.05, \quad 1.21 \\
\& 1.46\end{array}$ & $\begin{array}{l}0.7,3.43 \& \\
2.75\end{array}$ & $\begin{array}{lll}30.17, & 53 \quad \& \\
23 & & \end{array}$ \\
\hline 2 & Fabricated & $2.46,6.87 \& 12$ & $\begin{array}{l}-15.1,-17.3 \&- \\
13.7\end{array}$ & $\begin{array}{ll}1.6, & 1.2 \& \\
1.5 & \end{array}$ & $\begin{array}{l}1.66,1.2 \& \\
4.03\end{array}$ & $\begin{array}{l}67.4,17.4 \& \\
33.5\end{array}$ \\
\hline
\end{tabular}

II) 3D radiation pattern antenna: It has been observed that, From the figure $6,3 \mathrm{D}$ radiation pattern of the antenna have provided high directivities of $1.89 \mathrm{dBi}, 3.98$
$\mathrm{dBi} \& 4.86 \mathrm{dBi}$ at the frequencies of $2.4 \mathrm{GHz}, 6.47 \mathrm{GHz} \&$ $12 \mathrm{GHz}$.

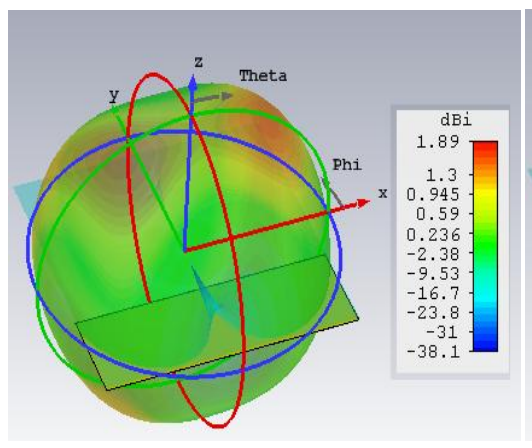

$6 a$

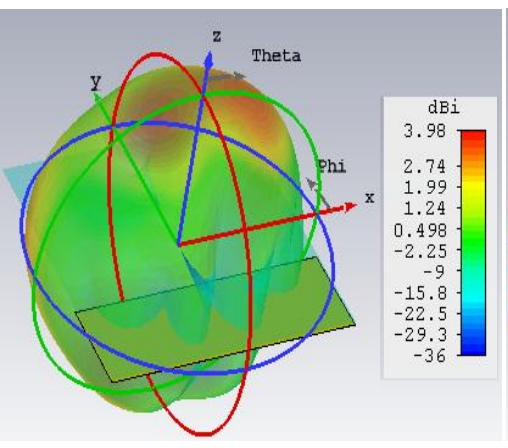

$6 \mathrm{~b}$

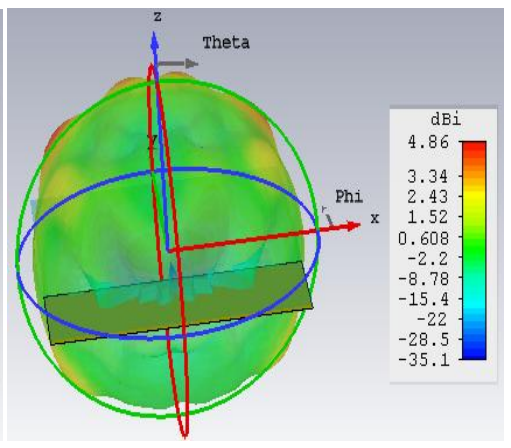

$6 \mathrm{c}$

Figure 6: 3D Radiation pattern the antenna at three bands: 6a: $2.4 \mathrm{GHz}, 6 \mathrm{~b}: 6.47 \mathrm{GHz} \& 6 \mathrm{c}: 11.95 \mathrm{GHz}$.

III) 2D radiation pattern of antenna: From the figure 7 , it has been stated that the main lobe direction of $175^{\circ} \&$ angular bandwidth of $78.8^{\circ}$ with magnitude of $1.58 \mathrm{dBi}$ at frequency of $2.5 \mathrm{GHz}$. Similar way the main lobe direction of $168^{\circ}$ and angular bandwidth of $67^{\circ}$ with magnitude of $3.77 \mathrm{dBi}$ at frequency of $6 \mathrm{GHz} \&$ side lobe level is of $-0.5 \mathrm{~dB}$. And at $3^{\text {rd }}$ band $12 \mathrm{GHz}$ the main lobe direction of $129^{\circ}$ and angular

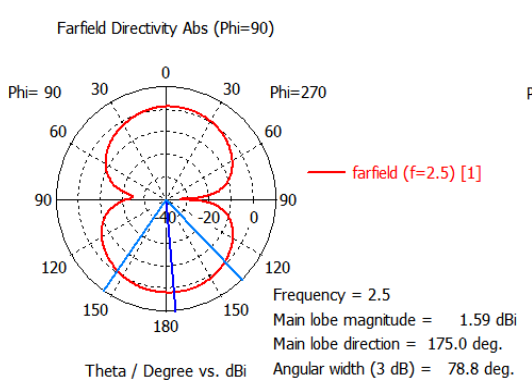

$7 \mathrm{a}$

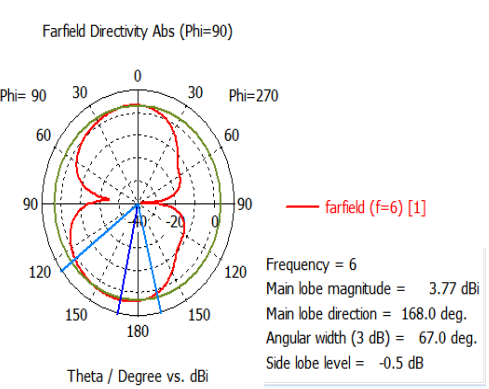

$7 b$ bandwidth of $46.3^{\circ}$ with magnitude of $3.43 \mathrm{dBi}$ at frequency of $6 \mathrm{GHz} \&$ side lobe level is of $-1.3 \mathrm{~dB}$. It has also observed from figure 7 , that the back radiation is very small at these operating frequencies because of use of proper ground plane. The radiation pattern obtained is of end fire at $1^{\text {st }}$ two bands and at 3rd band it is little bit Omni directional as shown figure $7 \mathrm{a}, 7 \mathrm{~b} \& 7 \mathrm{c}$.

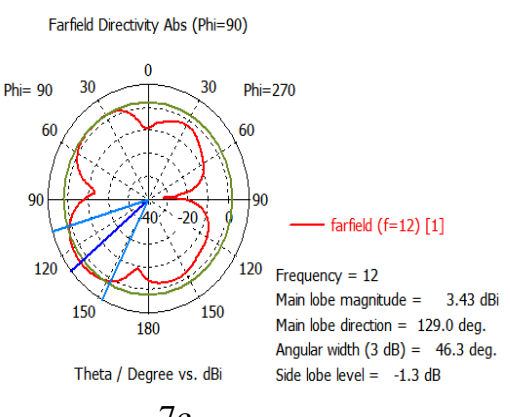

$7 \mathrm{c}$

Figure 7: Polar plot of the proposed antenna at 7a: $2.5 \mathrm{GHz}, 7 \mathrm{~b}: 6 \mathrm{GHz} \& 7 \mathrm{c}: 12 \mathrm{GHz}$

\section{IV) VSWR of proposed antenna:}

The figure 8 shows the VSWR plot \& from this figure, it has been observed that the value of VSWR at three the frequencies $2.32 \mathrm{GHz}, 6.47 \mathrm{GHz} \& 11.95 \mathrm{GHz}$ are 1.05 , $1.21 \& 1.46$ which are best for WiFi, WiMAX and $5 \mathrm{G}$ communication shown in figure $8 \mathrm{a}$. The VSWR value describes the proper impedance matching between feed line \& source applied so it must be used between 1 to 2 for proper radiation antenna. The VSWR vaules of fabricated antenna are 1.6, 1.2 and 1.5 at resonating frequancies of $2.46 \mathrm{GHz}$, $6.87 \mathrm{GHz}$ and $12 \mathrm{GHz}$, these values are perfeectly matched with simulated results shown in figure $8 \mathrm{~b}$. 


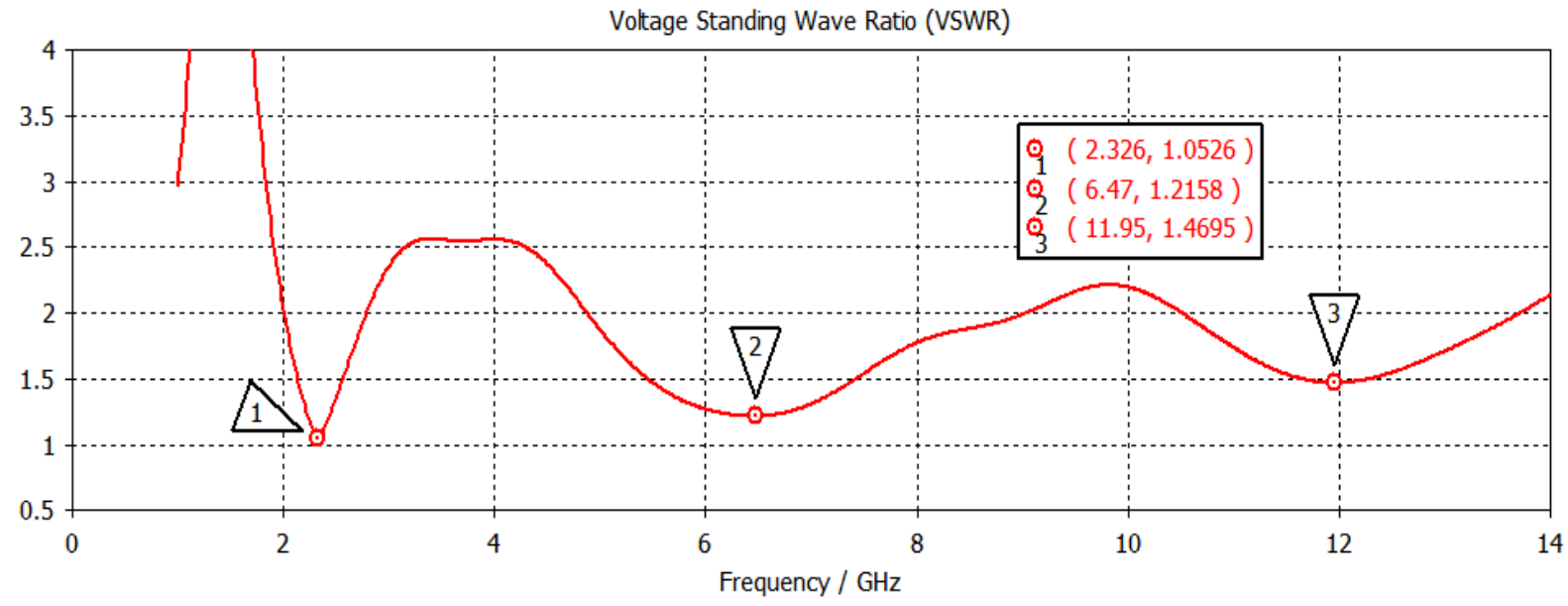

$8 \mathrm{a}$

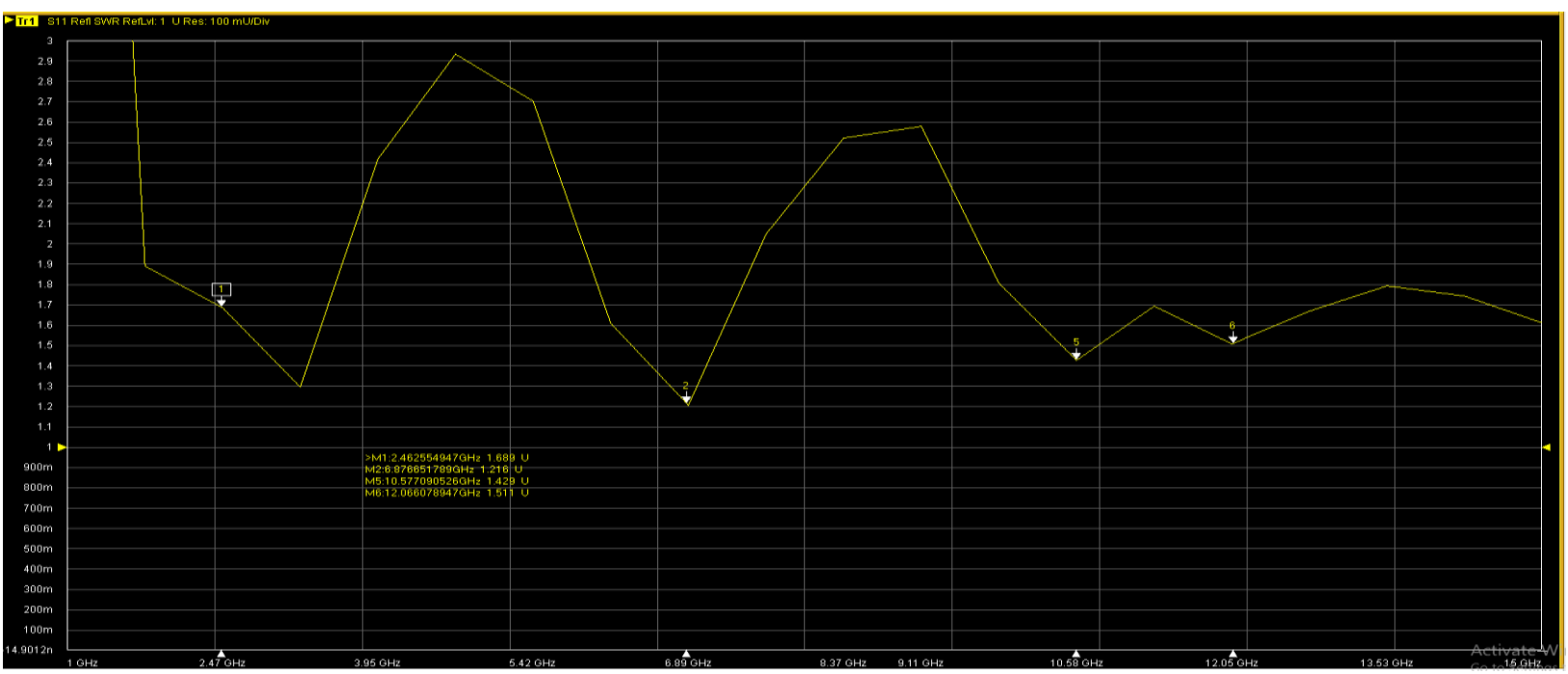

$8 b$

Figure 8: VSWR of antenna, 8a: Simulated \& 8b: Fabricated

Efficiency: The efficiency of antenna calculated by the ratio of power radiated by an antenna to the total input power fed to antenna.

The total efficiency differs from radiation efficiency due to losses takes place because of impedance mismatch.

$$
\eta t=\eta r * Z I
$$

eq (3)
Where $\eta \mathrm{t}=$ total effeciency, $\eta \mathrm{r}=$ radiation effiecincy, $\mathrm{ZI}=$ Impendace mismatch loss.

From figure 9, it has been observed that the proposed antenna radiated at 3 frequancy bands. So the radiation and total efficiecy at three frequency bands are $78.83 \%$ $\& 76.61$ at a frequency of $2.32 \mathrm{GHz}, 97.98 \%$ \& $95.63 \%$ at a frequency of $6.47 \mathrm{GHz}$ and $97.88 \%$ \& $94.21 \%$ at $11.95 \mathrm{GHz}$.

1D Results $\backslash$ Efficiencies [Magnitude]

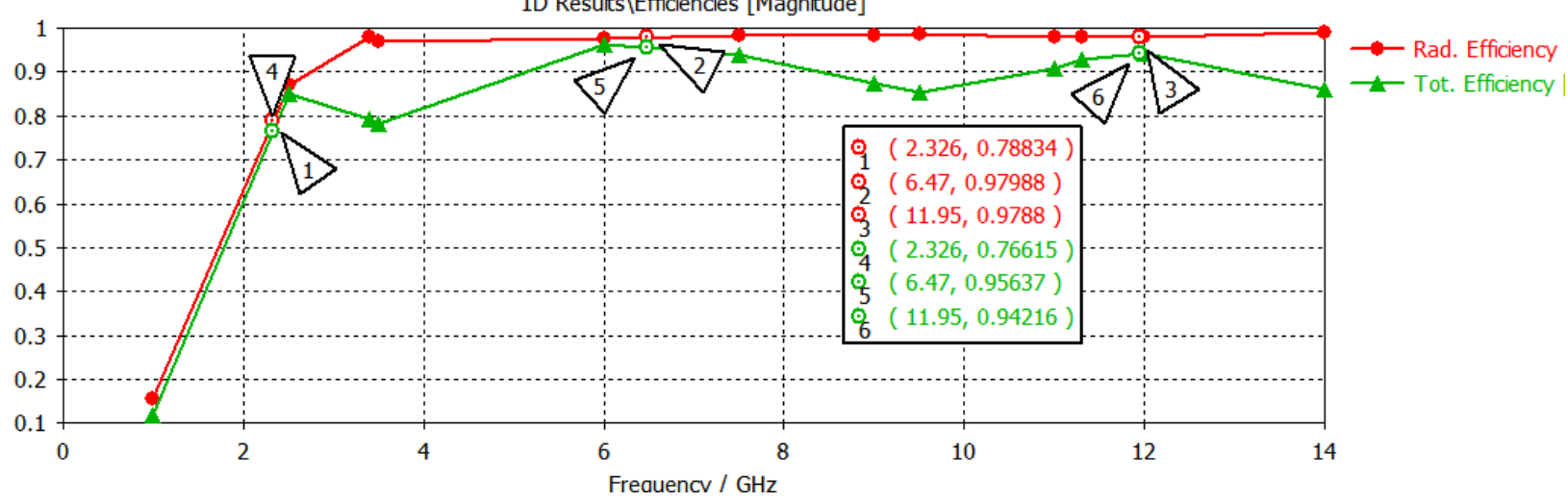

Figure 9: Radiation \& total efficiency of the proposed antenna 
4. Fabricated Results: The figure10 shows that return loss plot of fabricated antenna and from figure, it has been observed the fabricated antenna provides four frequency bands $1.75 \mathrm{GHz}, 3.95 \mathrm{GHz}, 7.6 \mathrm{GHz}$ and $12 \mathrm{GHz}$. The proposed antenna provides simulated and tested results are nearly same. The fabricated antenna provides one extra band in comparison with simulated results. In fabricated results also the bandwidth is improved due to use of low dielectric constant, jeans as textile material and partial ground structure. The fabricated antenna is tested with Anthrusu VNA of $20 \mathrm{GHz}$.

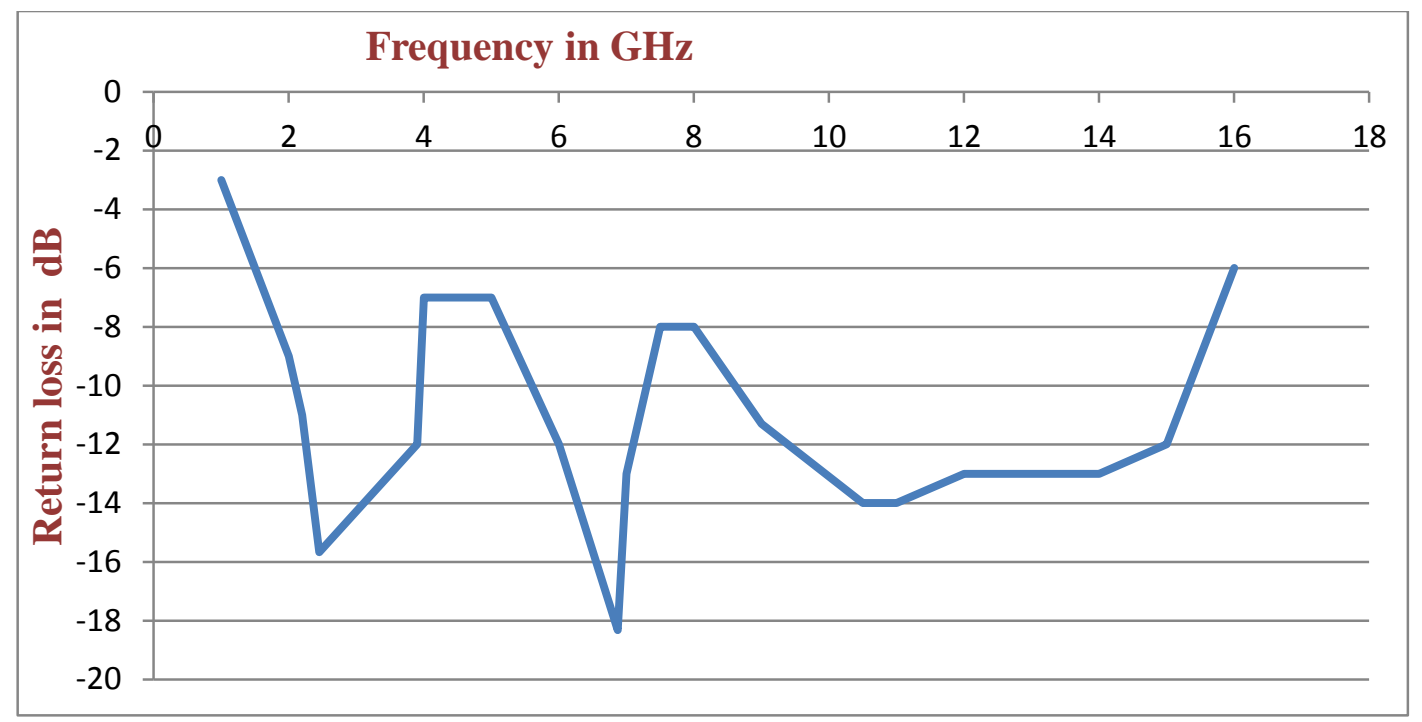

Figure 10: Return Loss of the fabricated antenna

The table 3 shows that the comparison of simulated results of designed antenna for three frequency bands and table 4 shows that the comparison of proposed work carried out \& previous work done.

Table 3: Simulated Results

\begin{tabular}{|c|c|c|c|c|c|}
\hline \multirow{3}{*}{$\begin{array}{l}\text { Sr } \\
\text { No }\end{array}$} & \multirow{3}{*}{ Parameter } & \multicolumn{3}{|c|}{ Proposed antenna } & \multirow{3}{*}{$\begin{array}{l}\text { Textile antenna for microwave } \\
\text { wireless power transmission } \\
\text { Resonating Frequency (GHz) } \\
3.42,9.73 \& 11.17\end{array}$} \\
\hline & & \multicolumn{3}{|c|}{ Resonating Frequency (GHz) } & \\
\hline & & Fr1 $1=2.32$ & Fr2 $=6.47$ & Fr3=11.95 & \\
\hline 1 & Return loss $\mathrm{S} 11$ in $\mathrm{dB}$ & -31.827 & -20.227 & -14.420 & $-17,-18 \&-26$ \\
\hline 2 & VSWR & 1.05 & 1.21 & 1.46 & NA \\
\hline 3 & Bandwidth & $700 \mathrm{MHz}$ & $3.43 \mathrm{GHz}$ & $2.75 \mathrm{GHz}$ & $50 \mathrm{MHz}, 200 \mathrm{MHz} \& 700 \mathrm{MHz}$ \\
\hline 4 & $\%$ Fractional Bandwidth & 30.17 & 53.00 & 23.00 & NA \\
\hline 5 & Directivity in $\mathrm{dBi}$ & 1.89 & 3.98 & 4.86 & $3.353,4.2 \& 5.1$ \\
\hline 6 & Radiation Efficiency (\%) & 78.83 & 97.98 & 97.88 & 87.2 \\
\hline 7 & Total efficiency (\%) & 76.61 & 95.63 & 94.21 & 89.6 \\
\hline
\end{tabular}

Table 4: Comparison between proposed antenna designs with other literature reported

\begin{tabular}{|c|c|c|c|c|c|c|c|c|}
\hline $\begin{array}{l}\text { Refer } \\
\text { ence }\end{array}$ & Technique & $\begin{array}{l}\text { Substrate } \\
\text { and \&r }\end{array}$ & $\begin{array}{l}\text { Operating } \\
\text { frequency } \\
\text { GHz }\end{array}$ & $\begin{array}{l}\text { Overall } \\
\text { Dimensions } \\
\text { mm }\end{array}$ & $\begin{array}{l}\text { S11 } \\
\text { Parameters } \\
\text { dB }\end{array}$ & $\begin{array}{l}\text { Bandwidth/ } \\
\% \\
\text { Bandwidth }\end{array}$ & VSWR & $\begin{array}{l}\text { Applications } \\
\text { Mentioned }\end{array}$ \\
\hline [2] & $\begin{array}{l}\text { Rectangular } \\
\text { shape \& Inset } \\
\text { feed }\end{array}$ & $\begin{array}{l}\text { Jeans } \varepsilon r= \\
1.67\end{array}$ & $\begin{array}{l}\text { Single } \\
\text { band } 2.45\end{array}$ & $\begin{array}{l}\mathrm{W}=45, \mathrm{~L}=53, \\
\mathrm{Hs}=2.84 \& \text { full } \\
\text { ground }\end{array}$ & -15.76 & $60 \mathrm{MHz}$ & 1.38 & $\begin{array}{l}\text { Wi-Fi } \\
\text { communication }\end{array}$ \\
\hline
\end{tabular}


"Design of Wearable Multiband Circular Microstrip Textile Antenna for WiFi/WiMAX Communication"

\begin{tabular}{|c|c|c|c|c|c|c|c|c|}
\hline [3] & $\begin{array}{l}\text { Dual mode, } \\
\text { Rectangular } \\
\text { ring and inset } \\
\text { feed }\end{array}$ & $\begin{array}{l}\text { On body } \\
\text { phantom }\end{array}$ & $\begin{array}{l}\text { Single } \\
\text { band } 2.45\end{array}$ & $\begin{array}{lr}\text { Patch } & 52.2 \quad \mathrm{x} \\
52.2 & \text { ground } \\
\text { plane } 80 \times 80\end{array}$ & -31 & NA & NA & $\begin{array}{l}\text { On Body } \\
\text { communication }\end{array}$ \\
\hline [4] & $\begin{array}{l}\text { Reconfigurable } \\
\text { antenna, back } \\
\text { to back snap on } \\
\text { button }\end{array}$ & $\begin{array}{l}\text { Foam } \\
\text { with air }\end{array}$ & $\begin{array}{l}\text { Dual band } \\
2.45 \& 5.8\end{array}$ & $\mathrm{~L} 1=60, \mathrm{~W} 1=55$ & $-15 \&-18$ & NA & $\begin{array}{l}\text { Between } \\
1 \text { to } 2\end{array}$ & $\begin{array}{l}\text { Wearable textile } \\
\text { antenna }\end{array}$ \\
\hline [5] & \begin{tabular}{l}
\multicolumn{2}{l}{ Rectangular } \\
patch for \\
different \\
substrate
\end{tabular} & $\begin{array}{l}\text { Cotton } \\
1.60, \\
\text { Polyester } \\
1.90, \\
\text { Lycra } \\
1.90 \text { and } \\
\text { Cordura } \\
1.50\end{array}$ & 2.4 & $\begin{array}{l}\text { WxL= } 46 \times 53 \\
43 \times 50, \\
48 \times 54\end{array}$ & $\begin{array}{l}-32, \\
35 \\
29 \\
31\end{array}$ & $\begin{array}{l}97, \\
50,\end{array}$ & $\begin{array}{l}2.4, \\
1.0879, \\
1.0944, \\
1.0917\end{array}$ & NA \\
\hline [6] & $\begin{array}{lr}\text { Moon strip } \\
\text { shape for } \\
\text { Multiband }\end{array}$ & $\begin{array}{l}\text { Jeans } \varepsilon \mathrm{r}= \\
1.7\end{array}$ & $\begin{array}{ll}5.44 & \& \\
10.15 & \end{array}$ & $\begin{array}{l}\text { Moon diameter } \\
26 \& \text { substrate } \\
50 \times 50\end{array}$ & $-24 \&-23$ & NA & NA & $\begin{array}{l}\text { Satellite } \\
\text { application }\end{array}$ \\
\hline [7] & $\begin{array}{l}\text { Circular }- \\
\text { polarized } \\
\text { textile antenna } \\
\text { diamond shape }\end{array}$ & $\begin{array}{l}\text { Thin } \\
\text { textile } \\
\text { spacer } \\
1,65 \text { to } \\
1.75\end{array}$ & ISM 2.4 & $\begin{array}{l}\text { Diamond } \\
\mathrm{s}=23.3, \\
\mathrm{ca}=5.6, \mathrm{lg}=17.28 \\
\text { line feed }\end{array}$ & -35 & $\begin{array}{l}7.2 \% \\
\text { fractional }\end{array}$ & NA & $\begin{array}{l}\text { Wearable } \\
\text { garments }\end{array}$ \\
\hline [8] & $\begin{array}{l}\text { Dual band, } \\
\text { rectangular } \\
\text { dual L shape }\end{array}$ & $\begin{array}{l}\text { Jeans } \\
\text { cloth } \quad \varepsilon r \\
=1.7\end{array}$ & $\begin{array}{l}\text { Dual band } \\
3.17 \quad \& \\
5.04\end{array}$ & $\mathrm{Wp}=25, \mathrm{Lp}=40$ & $-24,-18$ & $100 \& 30$ & $\begin{array}{l}1.86 \\
1.79\end{array}$ & Military \\
\hline [9] & $\begin{array}{l}\text { Wearable } \\
\text { textile antenna }\end{array}$ & $\begin{array}{l}\text { Jeans } \quad \varepsilon r \\
=1.6\end{array}$ & 2.45 & $\begin{array}{l}\text { Rectangular } \\
\text { shape Wp }=54 \text {, } \\
\text { Lp=46.6 }\end{array}$ & -32.57 & NA & 1 to 2 & $\begin{array}{l}\text { Wearable } \\
\text { application }\end{array}$ \\
\hline $\begin{array}{l}\text { Proposed } \\
\text { Work }\end{array}$ & $\begin{array}{l}\text { Circular } \\
\text { shape with } \\
\text { slits \& partial } \\
\text { ground }\end{array}$ & $\begin{array}{l}\text { Jeans \&r } \\
=1.7\end{array}$ & $\begin{array}{l}\text { Triple } \\
\text { band } 2.45, \\
6.47 \quad \& \\
11.95\end{array}$ & $\begin{array}{l}\text { Circular patch } \\
R=14 \text {, slits of } \\
5 \times 5 \& 10 \times 10 \text {, } \\
\text { Ground plane } \\
86 \times 28\end{array}$ & $\begin{array}{l}-31.8,-20.2 \\
\&-14.4\end{array}$ & $\begin{array}{l}700,3430 \& \\
2750\end{array}$ & $\begin{array}{l}1.05, \\
1.21 \\
1.46\end{array} \&$ & $\begin{array}{l}\text { Wi-Fi, WiMAX } \\
\& \quad 5 G \\
\text { communication }\end{array}$ \\
\hline
\end{tabular}

\section{CONCLUSION}

In the proposed design, the circular microstrip textile antenna with edge feed has been designed at $2.4 \mathrm{GHz}$ frequency \& provided return loss of $-31.827 \mathrm{~dB}$. The designed antenna also provided the 2 additional bands of frequencies $6.47 \mathrm{GHz} \&$ $11.95 \mathrm{GHz}$ due to use of 2 square slits and partial ground. The radiated efficiencies of antenna are $78.83 \%, 97.98 \% \& 97.88$ and total efficiencies are $76.61 \%, 95.63 \& 94.21$ at the frequency bands $2.32 \mathrm{GHz}, 6,47 \mathrm{GHz} \& 11.95 \mathrm{GHz}$. So it has been concluded that the proposed antenna is radiating with efficiency around $90 \%$ at multiple bands.

From the simulated and fabricated results, it is concluded the proposed antenna provided bandwidth improvement from $0.7 \mathrm{GHz}$ to $2.75 \mathrm{GHz}$ and both simulated \& fabricated results are validated.

\section{ACKNOWLEDGEMENTS}

The author would like to thank the review committee and my research guide Dr. Sanjay Kumar Gowre for his valuable guidance \& motivation. The author also thankful to SVERI's College of Engineering, Pandharpur and research center, Department of Electronics \& communication, BKIT Bhalki for motivating \& support.

\section{REFERENCES}

1. Nikhil Kumar Singh, Vinod Kumar Singh, Naresh B", Textile antenna for microwave wireless power transmission", International Conference on Computational Modeling and Security (CMS2016) Procedia Computer Science 85 (2016) 856-861.

2. Husain Bhaldar, Sanjay Kumar Goware, Mahesh S Mathpati, Ashish A Jadhav",Design of high gain wearable rectangular microstrip textile antenna for wireless application",International Journal of Innovative Technology and Exploring Engineering (IJITEE) DOI: 10.35940/ijitee.C8478.039520 ISSN: 2278-3075, Volume-9 Issue-5, March 2020. 
3. Carlos Mendes, Custódio Peixeiro, " On-Body transmission performance of a novel dual-mode wearable microstrip antenna ", IEEE Transactions On Antennas And Propagation, VOL. 66, NO. 9, SEPTEMBER 2018.

4. Shengjian Jammy Chen, Damith Chinthana Ranasinghe", Arobust snap-on button solution for reconfigurable wearable textile antennas", IEEE Transactions On Antennas And Propagation, VOL. 66, NO. 9, SEPTEMBER 2018.

5. Pranita Manish Potey, Kushal Tuckley, "Design of wearable textile antenna with varioussubstrate and investigation on fabric selection", 3rd International Conference on Microwave and Photonics (ICMAP 2018), 9-11 February 2018.

6. Anurag Saxena,Vinod Kumar Singh,"A moon-strip line antenna for multi-band applications at $5.44 \mathrm{GHz}$ resonant frequency",4th International Conference on Advances in Electrical, Electronics, Information, Communication and Bio-Informatics (AEEICB-18), 2018.

7. Idellyse Martinez and Douglas H. Werner,"Circularpolarized textile based antenna for wearable body area networks", IEEE transaction 978-1-5386-71023/18/\$31.00@2018 IEEE.

8. Rama Sanjeeva Reddy \& Amulya kumar, "Dual band circular polarized wearable antenna for military applications", 2018 International CET Conference on Control \&Communication, July 2018, 978-1-5386-4966-4/18/\$31.00 @2018 IEEE.

9. Sweety Purohit, Falguni Raval, "Wearable textile patch antenna using jeans as substrate at $2.45 \mathrm{GHz}$ ", International Journal of Engineering Research \& Technology, ISSN 2278-0181, Vol 3, issue 5 may 2014.

10. Jiao Zhang, Sen Yan and Guy A.E Vandenbosch," Miniature network for aperture- coupled wearable antennas", IEEE Transactions on Antennas and Propagation, Vol.65, no. 5 may 2017.
11. Yiye Sun, Sing Wai Cheung, Tung Ip Yuk, "Design of a textile ultra-wideband antenna with stable performance for body-centric wireless communications", Published in IET Microwaves, Antennas \& PropagationAccepted on 3rd July 2014 doi: 10.1049/iet-map.2013.0658.

12. Punith S, Praveenkumar S K, Abhinandan and Mohammed Ahmed, "A novel multiband microstrip patch antenna for $5 \mathrm{~g}$ communication", published in Science Direct, Procedia Computer Science 171 (2020) 2080-2086.

13. S. Ashok Kumar, Arun Raj, T Shanmugananthan, "Analysis and design of cpw fed antenna at ism band for biomedical applications", Alexandria Engineering Journal (2018). http://dx.doi.org/10.1.1016/j.aej.2017.02.008, 57, 723-727. Available at www.elsevier.com/locate/aej.

14. Seyed Mohsen and Majid Afsahi, "Compact and ultra-wideband cpw fed square slot antenna for wearable applications", International Journal of Electronics and Communications (AEU), 106 (2019) 108-115. Contents lists available at Science Direct.

15. Sandeep Singh Sran, Jagtar Sivia, "ANN and IFS based wearable hybrid fractal antenna with dgs for s, c, and x band application", International Journal of Electronics and Communications (AEU), PII:S1434-8411(20)31206-1,

DOI: https://doi.org/10.1016/j.aeue.2020.153425, 18 August 2020.

16. A. Degiovanni, R. Bonomi, S . Verdu and R. Wegner, "High gradient RF test results of S- band and C-band cavities for medical linear accelerators", Nuclear Inst. and Methods in Physics Research, A 890 (2018) 1-7, https://doi.org/10.1016/j.nima.2018.01.079. 